\author{
Горана С. РАИЧЕВИЋ \\ Универзитет у Новом Саду \\ Филозофски факултет
}

Оригинални научни рад

Примљен: 01. 10. 2016.

Прихваћен: 10. 02. 2017.

\title{
ЈЕЗИК, БИЋЕ, ИДЕОЛОГИЈА: ЕСЕЈИСТИЧКИ ДИСКУРС РАДОМИРА КОНСТАНТИНОВИЋА О ПОЕЗИЈИ СРПСКЕ МОДЕРНЕ ${ }^{* *}$
}

\begin{abstract}
У раду се полази од тезе да је Р. Константиновић своју теоријску конструкцију контроверзне Филозофије паланке (1969) - односно њен први део, у којем се теоријски образлаже и критикује тзв. култура паланачког света - у највећој мери изводио користећи се појмовима, идејама и мотивима песништва и критичке мисли који припадају раздобљу српске модерне (1901-1914). Из тога би произилазило да су есеји о песницима ове епохе, а посебно они посвећени Милану Ракићу, Сими Пандуровићу и Владиславу Петковићу Дису, формирани у основи пре него што су објављивани у Трећем програму (1970-1981) и потом обједињени у осмотомном есејистичком делу Биће и језик (1983). У раду се даје кратка анализа Константиновићевог есејистичког дискурса како би се показало да је овај, иако претендује на филозофичност и универзалност, темељно одређен пре свега ауторовим поетичким, али и идеолошким, парцијалним и пристрасним полазиштем.

Кључне речи: поезија српске модерне (1901-1914), импресионизам, филозофија паланке, Р. Константиновић (1928-2011).
\end{abstract}

Позната је чињеница да је рецепција песништва српске модерне пролазила кроз различите фазе, те да се кретала од оспоравања до „рехабилитације” - када се изнова указивало на специфичности ове прве праве „уметничке" поезије у српској књижевности, као и њене поетике, те на њену историјску, али и универзалну, естетску и општечовечанску вредност. Разлози оштрих критика били су вишеструки, али их суштински треба тражити у домену епохалне поетичке промене. Епоху коју ће многи касније називати златним добом српске културе од следећег нараштаја делила је катаклизма Великог рата, који је, осим материјалног разарања, донео и корениту промену темељних вредности: уместо тежње ка приближавању западним узорима,

\footnotetext{
*goranaraicevic@ff.uns.ac.rs

** Рад је настао у оквиру пројекта 178005 , који финансира Министарство просвете, науке и технолошког развоја Р. Србије.
} 
уместо поповићевског позива на подражавање културних и песничких образаца, одбачена је уморна западна култура у име нових, свежих, природних, самородних и неевропских врела инспирације, а са њом и формални окови западњачког версификацијског канона. Међутим, ако је, судећи према уоченим законитостима унутрашњег уметничког развитка, било сасвим природно да се међуратни песници супротставе генерацији својих „очева”, враћајући се импулсима романтичарског стваралаштва и песницима романтичарске епохе, очекивано враћање српској грађанској поезији после Другог светског рата изостало је, и то у великој мери и захваљујући томе што су и култура и књижевност у другој Југославији од самог почетка имали снажан идеолошки набој. Занимљиво је, међутим, да су педесетих година (дакле у време када су полемике о слободи стваралаштва уопште и постале могуће) ствараоци и критичари ангажовани у одбрани аутономности уметности од налога соцреалистичке естетике, имали такође мало лепих речи о песништву српске модерне. Штавише, приметно је да су неки од најодважнијих и најумнијих критичара соцреализма (или, како се то онда говорило, „реализма”) у књижевности, бранећи своје право на модерност и „модернизам”, одбацивали целу епоху прве српске модерне - као „непесничку”, чиме су - свесно или не - идеолошки обојеном отпору према раздобљу највећег успона српске грађанске културе дали и алиби у виду теоријског и естетичког оправдања. Тако су се Зоран Мишић, састављач утицајне Антологије српске поезије из 1953. године и Миодраг Павловић, и сам песник, те од Мишића ништа мање значајан антологичар, и књижевни критичар, поводом поезије модерне оглашавали чак и врло оштрим судовима, одричући појединим песницима ове епохе сваку уметничку вредност. Нова читања поезије првог таласа српског модернизма, која потичу из последње четвртине 20. столећа, могла би се разумети и као покушај да се укаже на то да о овој епохи није речена последња реч: радило се пре свега о књигама Д. Витошевића (Српско песништво 1901-1914, 1976) и П. Палавестре (Историја модерне српске књижевности: Златно доба 1892-1914, 1986). Интересовање за модерну настављено је и почетком новог столећа када настају књиге М. Ненина (Српска песничка модерна, 2006) и Ј. Делића (О поезији и поетищи српске модерне, 2008), док је Л. Којен, у покушају ревалоризације овог песништва, 2001. године саставио Антологију српске лирике (1901-1914). Последњих година чине се напори да се српско грађанско друштво и његова култура с почетка 20. века осветле на један свеобухватан и систематичан начин, што је гест који свакако говори афирмативно о савременој култури сећања, али и упућује на закључке да се ради о својеврсном одговору на претходно, другачије, различитим чиниоцима условљено историјско и вредносно виђење ове епохе.

О Константиновићевом тумачењу поезије српске модерне и њених песника - од којих су сви присутни у осмотомном есејистичком делу Биће и језик у искуству песника српске културе двадесетог века (Београд 1983) - није писано много. Овог аутора - који се као песник огласио управо почетком 50-их година, и чија је поезија по модернистичкој поетици била сродна с тада критикованим, новаторским песништвом Попе и Павловића, шира читалач- 
ка публика није запамтила ни по стиховима ни по романима, које је такође писао, већ по књизи Филозофија паланке (1969), која се, у данашње време, нашла у жижи једног ванкњижевног полемичког спора. О томе колики је емоционални и интелектуални напор уложен у њену апологију или демонизовање сведочи и чињеница да се у складу са прихватањем једног од поларизованих ставова (да се, са једне стране, ради о „генијалној књизи” а са друге о „библији српског аутошовинизма”) може открити и идентитетска позиција једне од страна у оквиру којих се данас размишља о прошлости и будућности српске културе. Расправе о овој студији која претендује на универзалност, и у којој се национална култура тумачи као затворен систем паланачког духа, што је, захваљујући балканским патријархалним колективистичким нагонима српског народа, држе заглављену у прошлости, не дајући јој да се уклопи у токове општег европског и светског напретка, пуне и данас ступце дневне и периодичне штампе. Такође, организују се (поводом ове књиге и њених основних теза) и научни скупови, пишу монографске и есејистичке студије. Међутим, упркос томе што се нашло у центру медијске пажње, те доживело и неколико издања, тешко је одговорити на питање о стварној рецепцији овог дела у ширим читалачким круговима, и то захваљујући пре свега његовој херметичности. Неразумљивост барем првог дела ове расправе која претендује на филозофичност и универзалност крије се са једне стране у апстрактном начину аргументације што барата само појмовима ван сваке врсте историјске и контекстуалне утемељености, а са друге у очигледним противречностима изнесених судова. Када већ на самом почетку паланачки дух припише облицима колективистичке, племенске свести и када устврди да према том духу појединац може заузети или став прихватања или побуне, Константиновић ће брже-боље изрећи тезу да и та побуна није ништа друго до средство духа паланке (Константиновић 2006: 6). ${ }^{1}$ Тако, читалац који схвати да аутор дух паланке жели да представи као „дух племена у агонији” (Исто: 289) - као продукт културе која није у стању да превазиђе нормативност и затвореност племенске (патријархалне) свести и да се модернизује - те сходно томе претпостави да ће уследити апологија сваког индивидуалистичког стремљења усмереног против наметнутих стега заједнице, уместо тога проналази само оштру критику индивидуализма, који се не открива само као неадекватно средство такве побуне већ се, у врло специфичној Константиновићевој аргументацији, представља управо као његов производ и манифестација.

Велику тешкоћу у дефинисању овог протејског Константиновићевог стања или ступња културе, који он назива паланачким духом, представља и чињеница да у овој књизи непрестано недостаје дефиниција позитивне вредности, нешто што се паланци супротставља, мимо широко схваћеног појма „отворености”. Ако „племенски” колективизам није прихватљив у „непаланачком", вишем ступњу друштвене организације, шта би то требало да га замени? Ако је и сама индивидуалистичка побуна против колективистичког

\footnotetext{
${ }^{1}$ Сви даљи цитати су из овог издања.
} 
духа паланке опет само манифестација тог духа, какав индивидуализам је за Константиновића узоран и пожељан? Ако је то индивидуализам уметнички и стваралачки, како то да се у другом делу ове расправе, који носи наслов „Белешке”, управо на примерима стваралаштва из различитих епоха српске културе поткрепљују тезе из првог дела и објашњава деловање паланачког духа? Позитивних примера у „Белешкама” готово да и нема: тек у једној фусноти каже се да су само песници попут Лазе Костића, Милете Јакшића и Диса, и то само у неким тренуцима свог стваралаштва „припремали ослобођење од духа паланке" (Исто: 219). Од помињаних песника модерне посебне целине (нека врста продужених фуснота) посвећене су Ракићу, Пандуровићу и Дису, о којима су много шире и обимније студије понуђене у Константиновићевом покушају систематског приступа српској поезији прве половине 20. века, у поменутом Бићу и језику. Из оваквог следа ствари учинило би се да је овај аутор прво дефинисао појам и особености паланачког духа те да је затим, накнадно, објављујући један по један обимне и исцрпне есеје о српским песницима, трагао за аутентичним или мање аутентичним отеловљењима бића у појединачним песничким опусима. Међутим, Радомир Константиновић поезију и песнике српске модерне није узимао само као примере на којима ће доказивати деловање духа паланке, већ је и целокупан терминолошки и идејни апарат преузео управо из ове епохе, позајмљујући појмове, мотиве и идеје песника и критичара српске модерне. То би значило да су недвосмислена побуна и индивидуализам српских песника златног доба били познати Константиновићу и пре писања Филозофије паланке, те да је термине и мотиве овог песничког супротстављања баналности грађанске егзистенције он искористио како би формулисао полазишта властите побуне против паланачког духа, проглашавајући управо ове песнике и њихову поезију његовим еманацијама. Он је, дакле, свог „непријатеља” тукао његовим властитим оружјем. Не желећи да види појаву која је у европским оквирима била уочена много раније (појаву индивидуалистичке побуне уметника-ствараоца против грађанског филистарства), или сматрајући ту појаву неаутентичном, те заправо привидним и прикривеним деловањем духа паланке, Константиновић је описивао - неретко са високим степеном тачности на нивоу чињеница - поетичко опредељење, то јест, поетичка опредељења песника српске модерне, али и вредносна мерила српске књижевне критике тога доба. Ризикујући да се приклонимо духу паланке у којем, по овом аутору, влада „тиранија увида у све”, тиранија ,апсолутне јасности и јавности” (Исто: 16), покушаћемо да покажемо шта је овом аутору послужило као инспирација за формулисање основних теза о „неаутентичној”, „антистваралачки настројеној и затвореној” култури.

Када Константиновић говори о „прекоплотовском погледу” (Исто: 23), када жели да у духу паланке означи „силну радозналост за туђи живот”, онда не можемо да се не присетимо чувеног текста у којем је Јован Скерлић, а поводом Мисли Божидара Кнежевића, по повратку из „великог” света 1902. године изразио своје дубоко разочарење стањем које је затекао у својој малој Србији: „[...] цео наш живот збио се у међусобну мржњу, у лична прогоњења, 
у мрачну злобу, у вођење туђе бриге. Цела Србија постала је један велики ћепенак, са кога сваки по цео боговетни дан мисли о томе шта му сусед ради, ради чега се са женом свађа и шта има за вечеру...” Не можемо спорити да се овде ради о поклапању Скерлићевог и Константиновићевог доживљаја паланачког духа као оног који се исцрпљује у празној радозналости. Међутим, читалац Филозофије паланке који је добро упознат са Скерлићевим идејама о „солидарности” као кохезивном фактору и о раду за заједницу, уочиће убрзо да су оне за Радомира Константиновића у потпуности неприхватљиве. Оно што ће Скерлић, као неспорни ауторитет у свом добу, супротставити грамзивом егоизму стицања и амбиције (што неспорно представља пратећу појаву успона српског грађанства), због чега се по његовом мишљењу урушавало свако осећање ,људскога братства”, Константиновић ће видети као зов племена и традиције, њему надасве мрско отелотворење „духа народа” као неплодног и чак антиисторијског.

Са друге стране, као што смо рекли - за читаоца Филозофије паланке сасвим неочекивано - очигледне манифестације индивидуалистичког духа у поезији српске модерне Константиновић ће произвести у главне показатеље паланачког погледа на свет. Критички дискурс који налазимо у оним одељцима где се говори о индивидуалистичким идејама (које несумњиво јесу одлике поезије првог таласа нашег модернизма) наводе нас на закључак да је критичар духа паланке у српској култури преузимао управо скерлићевску улогу културног комесара или цензора, иако је за њега Скерлић неко из кога је „не једном проговарао глас паланке” (Исто: 247). Када, на пример, критикује концепт „паланачке љубави” (имајући на уму Ракића, Дучића, њихов љубавни ,аутизам”, те мотиве мртве драге код Пандуровића и Диса, али свакако и друге импресионистичке одлике које упућују директно на субјективизацију доживљаја и перцепције света, а које се очитују у овој поезији), Константиновић у ствари, на једној скерлићевској позицији, говори о индивидуализму који додуше „разбија стил”, али „разбија и саобраћање”. Зато што је, како каже, по свом дејству идентичан колективизму, овај индивидуализам (неаутентичан, јер се јавља као функција и средство духа паланке) по Константиновићу јесте „статички” и „некомуникативан”, индивидуализам „не бића већ монада" (Исто: 51).

Индивидуализам је, нађен у противљењу основном идеалу духа паланке, и у покушају ослобођења од њега, на овај начин јединствено средство самога тог духа, средство којим он себе успоставља пре свега: 1) као дух затворености и 2) као дух сигурности, што ће рећи као дубоко против - метафизички (јер емпиричко-проверљив, вулгарно-позитивистички) дух, али не мање и као против-мистички и против-песнички. Све што одликује твораштво личности (или личност твораштва): мисао, самоиспитивање, способност за духовно саобраћање са светом, за улазак у свет посредством мислене, дубље рационалне или мистичко-поетске делатности у том свету, овде одсуствује, а свему томе противи се индивидуализам, с његовим сумњичавим емпиризмом и његовим ускогрудим осећањем коначности свега (Исто: 48-49). 
Одлике паланачког духа и културе, тако, према овом аутору, углавном јесу особености једног специфичног пејтеровског, импресионистичког (дакле и те како европског) доживљаја света који налазимо у поезији Дучића, Пандуровића и Ракића - где се сусрећемо са лирским субјектом који полаже право на овоземаљску, личну срећу. Овоземаљско опредељење ове поезије, али посебно њен антиинтелектуализам, те фаворизовање чулности, емоције и интензивног доживљаја у тренутку, на рачун мишљења које унесрећује појединца усредсређеног на богатство и пуноћу доживљаја, поезије која не стреми трансценденталном знању, критиковали су и Константиновићеви савременици, посебно Мишић и Павловић - будући да су, први као критичар поезије, други као и сам песник, заступали другачији, и могло би се рећи, поетички дијаметрално супротан песнички концепт. Парнасовско наслеђе, класицистичка тежња ка равнотежи и јасности те склоност ка песничким сликама, тако су, као легитимни књижевни токови, проглашавани мање вредним од симболистичке тежње ка прекомерности, затамњивању смисла и музикалности песничког језика, од интелектуализма, чак церебралности трећег модернизма у српској поезији. Ипак, не треба заборавити ни прећутати да је Павловић, који је упркос томе што се у својој поезији приклонио другачијим песничким вредностима, дао и познато објашњење које се може схватити и као врста апологије песништва првог таласа модернизма. Када је, наиме, у есеју о Дучићу, поставио реторско питање зашто песници модерне нису за своје узоре узели француске симболисте, већ другоразредне парнасовце, откривајући слух за културноисторијске токове и процесе, Павловић је одговорио: зато што је српски књижевни језик и израз с почетка 20. столећа прво требало да се дисциплинује и нормативизује да би тек потом могао да се разара и деконструише: „Нашем песничком изразу требало је тада веће уметничке дисциплине, веће способности за наговештај и сугестију и за обухватање сложенијих душевних стања и мисаоних структура" (Павловић 2000: 132). ${ }^{2}$ Колико је значајно ово уважавање књижевноисторијских законитости и токова, и вредновање другачије песничке традиције, види се ако се оно упореди са констатацијама које је изнео Мишић у својој Антологији српске поезије из 1956. године:

И док се наш језички инструменат, по закону инерције, мирно и спокојно развијао у оном позитивистичком, антипоетском смеру у који су га 'здраворазумски' прописи упућивали, док су наши највећи артисти: Змај, Дучић, Ракић, Шантић и други стрпљиво усавршавали свој стих да би могао што успешније да изрази плитке, фамилијарне и мондене теме, права поезија, она која се није повиновала захтевима владајућег грађанског конформизма, остала је без своје естетике, пометена и недоречена, без ослонца у традицијама, туђин у своме рођеном језику, сва у грчевитом напону да пронађе излаз из зачараног круга предрасуда и конвенција (Мишић 1996: 131, курз. Г. Р.).

\footnotetext{
${ }^{2}$ Миодраг Павловић се, од свих својих савременика - „негатора” поетике модерне - највише „искупио”, пишући значајне есеје о Дучићу, Пандуровићу, Дису, Шантићу, Бојићу... Ракић је и код Павловића најнегативније оцењен, док је Дучић, по његовом мишљењу, неоправдано излаган презиру јер „спада у неколико најбољих песника овога језика”. Осим тога, Павловић недвосмислено овај период назива ,златним”.
} 
Чини се као да су ове реченице Константиновићу послужиле као пролегомена за расправу која неће оспорити само једну легитимну поетичку линију и историјски стадијум развитка српске поезије, већ ће саме поетичке особености овог песништва прогласити манифестацијом „духа паланке”. Тако је овај дух, по Константиновићу, у исто време и традиционалистички и ванвременски, а оно што је у њему временско јесте оно што му смета, а то је фаворизовање тренутка а не процеса. Паланачко је, за Константиновића, и узношење доживљаја које иде „до обоготворења” (Константиновић 2006: 20). Импресионистичко вредновање утиска који долази из спољашњег света и који узбуђује наша чула и искуство („,ствари вреде онолико колико су способне да нас узбуде" - тако карактеристично за западњачку културу декаденције оличену у Вајлдовом Дорјану Греју и Уисмансовом Дезенсенту) за Константиновића није део велике западне културе којој је и сам стремио, већ манифестација паланачког духа (Исто: 21). Према овом аутору, паланку карактерише и то што способност осећања добија поново највишу цену, вредност по себи, док су узроци ове осећајности увек изван субјекта: „Ја у свет излазим, овде, само по основне подстицаје, по 'храну' и 'материјал' за своју осећајност" (Исто: 65). Ирационална природа осећајности, међутим, по Константиновићевом начину резоновања, где се све противречности уклапају неком врстом псеудодијалектичког обрта у изречене тезе, не може бити достојан противник омраженој трезвености и рационалности које одликују паланку (а за које је инспирацију налазио у богданпоповићевским и скерлићевским захтевима за јасношћу поетског израза). Тако, између духа трезвености, који је прави израз „ћифтинског” духа и духа опијености осећајношћу „привидно потпуно међусобно неспојивих постоји једна снажна веза, и то не само по пореклу већ и по њиховом циљу: дух индивидуализма њих нужно ствара стварајући себе и нужно их садржава у самоме себи" (Исто: 69). Узимајући начело баналности, баналне филистарске егзистенције, као основу паланачког духа, ону исту баналност против које се тако отворено побунио Сима Пандуровић у песми „Данашњица” (1911): „Само не ово, само не баналност”, Константиновић је опет проглашавао неаутентичном побуном, маскираном манифестацијом паланке и паланачке свести. У есеју о Пандуровићу из Бића и језика овај песник (који је Константиновићу као најомраженији послужио као највећа инспирација) $)^{3}$ обележен је као гласноговорник паланачког нихилизма, индивидуализма што се родио у сусрету са смрћу и уплашио од самога себе (Исто: 196). У том смислу „псеудободлеријански” мотиви у Пандуровићевој „гробљанској” поезији за Константиновића представљају својеврсну „црну ренесансу” у племенској култури, која епоху препорода није доживела кад и други европски народи. Паланачки је, за Константиновића, и став „паланачко-против-паланачког аристократизма" (Исто: 81) који је проналазио код Милана Ракића, као што је паланачком проглашена и ,антимисаоност” овог песника, што ју је аутор Филозофије паланке видео (сасвим неосновано)

\footnotetext{
${ }^{3}$ Баналност, дан-ноћ (рационално-ирационално), заборав, лудило, песимизам, нихилизам - све су то мотиви које је Константиновић узео од Пандуровића.
} 
и код Његоша (узимајући као аргумент пример из Горског вијенца, а не песму Мисао) и претварајући је у чврсту константу српске „паланачке” културе. Иако је од свих песника модерне једино код Диса налазио аутентичну песничку линију која је успевала да пробије снажне окове паланачког духа, и код овог „богоданог” песника видео је Константиновић особине паланке: мотив „мртве драге” као објективизацију љубавне немоћи, мотив варке (то ће рећи - схватање света као илузије, што је основа платонизма), те мотиве лењости (пасивности), апокалиптичког утопизма и наивности (Исто: 124).

На крају, нужно је поставити питање: зашто је Радомир Константиновић употребио управо поетичке, дакле естетичке особености једног периода у развоју српске поезије, како би дефинисао једну наводно универзалну појаву - коју ће, међутим, у другом делу своје расправе везати искључиво за српску културу? Поготово је то необично ако се има у виду да се ради о првој правој индивидуалистичкој епохи у српској књижевности, поетички оријентисаној према европским књижевностима и европској традицији. Да је та критика јасно конкретизована без покушаја филозофске универзализације, онда бисмо могли да се послужимо аргументацијом којом се Слободан Јовановић послужио супротставивши се Светозару Марковићу и његовој критици чиновништва у Србији друге половине 19. века. Као што је Јовановић рекао да је аутор „Певања и мишљења” критиковао своју државу зато што је почела да се организује, тако бисмо и ми могли рећи да је и Константиновић критиковао српску поезију зато што је почела да се развија ритмом који је увелико личио на ритам и токове великих европских књижевности. Оно што је овај аутор, међутим, урадио представљало је априорно одбацивање поетике српске грађанске поезије, као чувара духа племена и колективистичких вредности, ${ }^{4}$ тако што су све очигледно присутне карактеристике индивидуализма и његовог супротстављања нормативности заједнице проглашене лажним и неаутентичним - „псеудо индивидуалистичким” вредностима. Подробна анализа појединачних есеја о Ракићу, Пандуровићу и Дису показала би, међутим, да је код ових песника Константиновићу сметало нешто сасвим друго, нешто што се проналази ван „лажног” индивидуализма, чије је идеје и мотиве сам сасвим некритички преузео градећи своју критичку конструкцију. Код Ракића и Диса то је била њихова родољубива поезија (коју су и други критичари проглашавали лошом и неаутентичном), а код Симе Пандуровића изгледа да је то била његова сувише грађанска биографија, која је после Другог светског рата и одредила његову судбину. Да је, у ствари,

4 „Индивидуализам духа паланке... има ово племе као идеал” (Константиновић 2006: 266). Нема сумње да се Константиновић у говору о „племену” послужио Винаверовим увидима у природу српског десетерца и народне поезије из студије „Језичне могућности” (Мисао 1923), где се каже да је у народној песми изражен само „народ” и „племе”, а не индивидуални човек. Међутим, Константиновић је судове овог иначе за њега узорног аутора извлачио из контекста (занемаривши и његову оданост народној песми и самом народу који ју је испевао) па је тако, приређујући избор из Винаверовог опуса, узимао само оне одломке који су му одговарали. Тако је, на пример, занемарено оно што је о епској песми Винавер написао у књизи Језик наш насушни (1952): „Интервали у гусларском певању одређени су готовим шаблонима. Али у шаблону једнако подрхтава нешто што није шаблон, што се од њега отима. (Трагична борба индивидуалнога, па чак и тренутнога, са вечним и устаљеним)...” 
заиста била реч о нечему другом, а не о објективној анализи непожељног и за Константиновића „псеудомодернистичког” ступња у развоју српске културе, види се посебно на примерима у којима је у окружје свог „разобличавања” паланке и паланачког духа овај аутор уводио терминологију и поетичка начела и оних песника који припадају неким другим епохама, и чија се поетика увелико разликује од импресионистичке осећајности песника модерне. На овим местима (дакле управо на линијама контрадикторних карактеристика којима је обележена култура затворености) целокупна Константиновићева конструкција опасно се приближава тачки пуцања. Тако се „обичан читалац” (још неснађен у амбивалентном вредновању колективног и индивидуалног) поново налази у чуду када се рационализму духа паланке одједном придодају и мистицизам и тајна, које је претходно овај аутор прижељкивао, а над којим се надвила сенка, за Константиновића такође неприхватљивог, песника Момчила Настасијевића, те када се специфичности Настасијевићеве поезије (отпор према глаголу, тајанство и сл.) као „универзалне” манифестације паланачког духа покушају да уклопе у окружје идеја и мотива песника из раздобља до Првог светског рата.

У маниру стилистичке критике која је са анализе формалних и језичких карактеристика књижевног дела прелазила, неким неприродним скоком (најчешће потпуно неуспешно), на објашњење његових значења и идеја, и Константиновић је, углавном на основу поетичких постулата једног периода у развоју српске књижевности, закључивао о „паланачком духу” читаве српске културе, везујући је за „тамни вилајет” племенског духа, који јој не да да се отргне из канџи прошлости и традиције и крене напред у будућност. У време када се, према познатом принципу двоструких стандарда, само великим и моћним нацијама признаје право на сећање и традицију (а не заборавимо и на то да „традиција” за Константиновића има негативну конотацију), верујем да је и нама малима потребно да разаберемо основе сваког идеолошког, дакле парцијалног и заинтересованог дискурса, који нам се представља као објективна расправа универзалних, филозофских вредности. ${ }^{5}$ То би у овом случају значило да се паланачки дух може тражити и сузбијати у областима текућег културног живота и културне политике, али никако и то да се овај може изводити из самог песничког, стваралачког импулса као облика једног или другог поетског израза или поетике. Овај рад представљао би и аргумент у прилог овој тези.

\footnotetext{
${ }^{5}$ Ово је важно и стога што се појављују тумачења да је у Филозофији паланке Константиновић критиковао социјалистичко друштво, што није само погрешно читање већ представља и фалсификовање наводне Константиновићеве одважности, чак дисидентства у односу на социјалистичку заједницу. Када иза неразумљиве аргументације откријемо шта је и зашто Константиновић стварно критиковао, онда се јасно види да ова књига недвосмислено подржава идеологију социјалистичке Југославије.
} 


\title{
ЛИТЕРАТУРА
}

Константиновић 2006: R. Konstantinović, Filosofija palanke, Beograd: Otkrovenje.

Мишић 1996: 3. Мишић, Критика песничког искуства (друго издање), Београд: СКЗ.

Павловић 2000: М. Павловић, Есеји о српским песнициима, Београд: Просвета.

\author{
Gorana S. Raičević
}

\section{LANGUAGE, BEING, IDEOLOGY: RADOMIR KONSTANTINOVIĆ'S ESSAYISTIC DISCOURSE ON THE POETRY OF SERBIAN MODERNA}

\section{(Summary)}

The paper starts from the thesis that Radomir Konstantinovic has built his theoretical construction named Philosophy of Palanka (a small town, village) published in 1969, mostly using terms, ideas and motives taken from the poetry and critical thought of the Serbian Moderna (1901-1914). That would mean that his essays on the poets M. Rakić, S. Pandurović and V. Petković Dis were conceived before being published primarly in the review Treći program and lately in the several volumes monograph named Being and Language (1983). The paper offers an analyses of Konstantinović's essayistic discourse in order to explain how its ambition to be seen as philosophic and universal one fails as the author's partial, ideological and biased standpoint is being exposed. 